Acta Hispanica (2020) Supplementum II: 609-616

\title{
LATINA HUMOR IN THE WORKS OF SANDRA CISNEROS
}

\author{
ZsóFIA ANNA TóTH \\ University of Szeged
}

\begin{abstract}
The paper discusses three works written by Sandra Cisneros, namely Woman Hollering Creek, The House on Mango Street and Caramelo, from the point of view of women's humor. With the help of these works, it is argued that Cisneros uses Latina humor in order to highlight intersectional problems concerning her identity and to reveal important facts and features about/of Latino/a existence. The point is made that Cisneros uses comedy and humor to redeem the pain and suffering through laughter instead of utilizing the tragic mode of artistic expression, hence she is able to secure survival and solutions to problems instead of a tragic wallowing in negativity (which interpretive way could also have validity concerning the occurrences which are narrated).
\end{abstract}

Keywords: Latina Humor, Sandra Cisneros, Woman Hollering Creek, The House on Mango Street, Caramelo.

In my paper, I intend to discuss how the use of humor can relieve the tension and often the pain of Latina existence. I intend to discuss this topic through the analysis of Sandra Cisneros' collection of short stories, Woman Hollering Creek primarily, but I also would like to include some comments about The House on Mango Street as well as Caramelo since all of these works are imbued by a fascinating sense of irreverence as well as an acute comic outlook on life that reverberate throughout the pages showing us life in all of its "normalcy and confusion" (Sypher, 1956: 254) just as only humor can do. I aim to argue that throughout these stories and cuentos/recuerdos (as she calls them), Cisneros while trying to create a synthesis of her ancestral traditions/cultures as well as those of the United States, she also unveils all of the struggles of Latina/Chicana existence and life situation(s), yet, she seems to overcome the possible negativity of all of the problems that she and Latina/Chicana women encounter through the use of humor. Regina Barreca is also of the opinion that women's use of humor is a mode of protest against the injustices of society: "[w]omen's humor emerges as a tool for survival in the social and professional jungles, and as a weapon against the absurdities of injustice" (1996: 2). Cisneros exactly does this with her humorous take on her own/her family's/her friends' etc. real life experiences. She protests against the injustices, she reveals the absurdities of life and actually with the help of humor she and her compatriots become survivors. Just like the corn that obviously often appears in her writing as a major and basic food source either with the color or the taste, the smell or the texture of this type of food etc. but the corn is a basic point of reference, a secure point of identification and always involves positive sentiments, corn is always love as opposed to wheat as an example. Similarly to Gloria Anzaldúa, Cisneros and her artistic output are like the corn (so atavistically, originally as 
well as symbolically American) as "[they] hold[s] tight to the earth - [and they] will survive the crossroads," because just like the corn, they are the "product[s] of crossbreeding" that can persevere "under a variety of conditions;" thus Cisneros as a person and as an author as well as her works are able to contribute to the creation of a new culture, new symbols and new meanings (Anzaldúa, 1987: 81).

Barreca while discussing women's humor also adds that it "is not only about telling jokes; it is about telling stories, and retelling stories that might once have been painful but can be redeemed through humor" (1996: 5). Again this is relevant about Cisneros' storytelling because her stories exactly aim to redeem those many painful memories and actually frequently terrible occurrences; she is precisely retelling the real stories in order to achieve redemption and freedom. In Caramelo, at some points, when the grandmother's story comes to be retold her voice butts into the narrator's voice as if they were talking and writing together and they (the narratorial as well as the character's voices) are in interaction. The Awful Grandmother complains that Cisneros is making up the story, it is a mentira (a lie), you exaggerate as she says: "Qué exagerada eres! [...] I have to exaggerate. It's just for the sake of the story" (2002: 92) - claims Cisneros trying to defend herself and her narration; then again "How you exaggerate! Where you get these ridiculous ideas from is beyond me" (2002: 98). Cisneros, thus, is not lying or is being ridiculous in her stories but she tries to retell them in a way to achieve redemption for all involved. As Donald McQuade et al. also opine, Cisneros' narrator/s and characters are always "doing loopity-loops and pirouetting" inside against all odds, hence, "[c]learly the narrator and her friends are survivors" even if they are damaged (1999: 2699). What is important is that they are indeed damaged but they do not let themselves be defined by this and with the help of humor they manage the internal pirouettes. However McQuade et al. also add that despite "the serious, painful themes of racism, sexism, and poverty, yet her voice is strong, playful, and often gracefully laced with Spanish words and phrases. She avoids the romantic clichés [...]" (1999: 2698). Cisneros never romanticizes anything (nothing is sacred enough for her to try to 'protect' it with false saccharine melodrama), not even romantic relationships, she often also treats them with acid wit while still showing us glimpses into the intensity of joy and/or pain that these entail. It is exactly her acid wit that reveals the naked truth about relationships. It is also true that the simultaneous use of English and Spanish has a special effect while the Spanish provides the utterances with ornamental quality while still revealing something deeply real about her intersectional identity. The narrators as well as the characters often switch codes (or intertwine the different languages) and juggle cultures similarly to Gloria Anzaldúa: "I am in all cultures at the same time, alma entre dos mundos, tres, cuatro [...] Estoy norteada por todas las voces que me bablan simultaneamente" (1987: 77). All of these cultures, traditions, customs, rituals, languages, expressions, phrases etc. are running simultaneously in their minds while continually living in parallel worlds at the same time. Cisneros tries to grasp and make us understand how they belong to all of the cultures that are in their lineage, and that they do not have/want to choose between them or prefer one of them over the other. 
Latinos/as-Chicanos/as are all of these cultures that are simultaneously operating in their minds and running in their blood.

Yet most importantly, Cisneros also makes fun of all this (languages, cultures, especially the Spanish and the Mexican - probably because she feels basically American and she feels that English is her first language and this causes her conflicts deep down), e.g. in Caramelo, when one of her aunts throws a jealous tantrum threatening to kill herself, Cisneros suddenly butts in with her narratorial voice making fun of Spanish language stating that it is more dramatic in Spanish and starts to rewrite it in Spanish too: "Me mato! iiiMe Maaaaatoooooooo!!!” (2002: 11). Additionally, at one point, when the grandfather is telling the love story of Popocatéptl and Iztacchíhuatl calling it "A Mexican love story" Lala asks him why the man killed the woman if he loved her so much, the Little Grandfather only guesses: 'I don't' know. I suppose that's how Mexicans love, I suppose" (2002: 57). In Bien Pretty, Cisneros again encounters this conflict within herself what/who she is - also declaring that she will never be able to make love in English any more after experiencing lovemaking in Spanish with her Mexican lover - but she still feels like an American 'barbarian' (this term barbarian often emerges in the stories concerning the alienated, 'de-cultured', Americanized offspring of originally Mexican families) because when they have a fight with her Mexican lover, he states that "I don't have to dress in a sarape and sombrero to be Mexican, Flavio said. I know who I am" (emphasis original, 2004: 151). The narrator obviously feels the sting and her reduction to being some 'mongrel' who is lost between definitions, languages, cultures and identities and tries to retaliate/retort but cannot because she is not able to speak proper Spanish and shouts only perro (dog) at Flavio instead of a real swearing like cabrón (as an example). Eventually she thinks to herself desperately: "I wanted to be Mexican at that moment, but it was true. I was not Mexican” (2004: 151-152). Réka Cristian also emphasizes the feeling of homelessness (2015), and I would add, (seeming) rootlessness that surfaces as a problem in Cisneros' stories (of forming/searching for identities). However, the whole situation is comic as she shouts perro at somebody instead of something really insulting revealing her clumsiness and partly proving Flavio right when she exactly wanted to do the opposite.

In Caramelo, the Awful Grandmother also shouts at her when she does not want to eat a Mexican food that has been produced since the time of the Aztecs: "Don't pretend you're not Mexican!" (2002: 55); what actually she is not, she is not pretending, because she is a mixture of all of these cultures and she cannot be a Mexican pure and simple. Yet, Cisneros also makes fun of being American, e.g. in Mericans, while the Awful Grandmother is praying in church, during their vacation in Mexico City, the kids are playing outside and some American tourists try to give them chicle (chewing gum) while they, as clever and opportunistic kids, play along but suddenly they speak English and the American tourists exclaim astonished: "But you speak English!" "Yeah," my brother says, "we're Mericans" (2004: 20) - and they even feel a little bit ashamed but again the whole scene is comic. In the very same short story, but in several other ones too, Cisneros 
also ridicules Catholicism and all of its rituals, prayers, the basic belief system etc., e.g. she asks in the voice of a child: "Why do churches smell like the inside of an ear? [...] And why does holy water smell of tears?" (2004: 19) - both of which are valid questions and the truth value is communicated through the humorous thinking of a child. Hence, the shock value of irreverence and iconoclastic behavior is lessened through humor. Cisneros is a real humorist, as Nancy Walker defined, as she is brave, intelligent, perceptive, she has a real insight, she is not be awed, what is more, she is irreverent and disrespectful; yet the criticism she articulates and presents is conveyed with great selfcommand and discipline (1988: 23-26).

According to Joanne R. Gilbert, women humorists are able to subvert the status quo and to initiate transformation/ change (herein lies their danger) exactly because they show resistance and are able to critique the dominant culture precisely due to their marginalized and distanced position (2004: 3-5). Although, it is true that Cisneros ridicules all of her cultures: American, Mexican, Mexican-American etc. Sandra Cisneros, being exactly at the crossroads of many marginalities/oppressions/exclusions, being at the intersections of various disadvantages (just to mention a few: gender, class and race etc.), is out there to make a change because she seemingly is always on the wrong side of the track, and she wants to break out and help others of her kind to make a better life. I agree with Réka Cristian that Cisneros (in the manner of a political writer) encourages her readers to transgress and break boundaries, to move beyond borders, realms and norms, and as a consequence, they will be able to set themselves free, also due to their multiplicity that will hence be acknowledged (2015). Consequently, Cisneros with her humorous take on her stories achieves more than just making us laugh, she also generates change, makes a difference and provides a toolkit for survival while turning La Llorona into La Gritona especially in the short story entitled Woman Hollering Creek but actually in every piece of writing since the joyful hollering, gritar, redeems the pain and suffering and this turns the possibility of the looming and threatening La Llorona into something positive while the abused, imprisoned and suffering female self is set free and starts hollering. Nobody seems to care why the creek is called La Gritona and nobody can explain it but the narrator is interested in it so much, and they warn her not to stay close to the water after dark because La Llorona might take her child and cause her trouble, but she defies everybody (her neighbors, Soledad (loneliness) and Dolores (pain and sorrow) especially) and through Felice (happiness) she understands La Gritona - but it is also true that through a real American experience of self-reliance, independence and individualism and sides with La Gritona, with comedy, and returns to Mexico (her homeland) to be happy, healthy, and most importantly, to stay alive.

Like in Woman Hollering Creek, in most of Cisneros' stories the comic, comedy and humor are the key to life as well as to the understanding of the complexity of life itself. Wylie Sypher is of the opinion that it is exactly the complexity of comedy that leads to the understanding of existence and declares that the frequent failure of understanding it theoretically results from oversimplification: "[i]ndeed, most of the theories of laughter 
and comedy fail precisely because they oversimplify a situation and an art more complicated than the tragic situation and art" (1956: 206). He even adds that comedy is much more powerful, expressive and encompassing than tragedy since it can tell and reveal much more about us, life, the world and the human existence than tragedy ever could: "[c]omedy seems to be a more pervasive human condition than tragedy" and " $[\mathrm{t}] \mathrm{he}$ comic action touches experiences at more points than tragic action" (Sypher, 1956: 206). Even more interestingly, Cisneros' kind of humor is rather low, and is very far from the elevated tragic approach, e.g. Caramelo is full of defecating, urinating, vomiting etc. but in Woman Hollering Creek we also have several similar occurrences e.g. in Never Marry a Mexican, it is discussed how somebody's bowels are almost gushing out during childbirth and how after that the stitches hurt in your lower parts etc., while in the meantime the husband (of this white/blue-eyed/redhead woman delivering his son) is cheating on her with a Latina lover whom he is not willing to acknowledge openly etc. In this same story, the Latina narrator tries to take revenge by various means but one of them is pushing gummy bears into intimate and hidden places and stuff of this woman (such as her cream or the central part of her Matryoshka doll etc.) in a rather childish manner. Although it is childish it has its point because such a behavior is so ridiculous and 'abnormal' (while the acts are obviously conscious since these gummy bears are strategically placed in such places that are not accessible to anyone, so it cannot be an accident) that either the husband has to say that he did it presenting himself a lunatic or to admit that his lover did this confessing to his infidelity and reveal his attachment to this Latina woman.

Cisneros often employs the perspective of a child and/or the narratorial voice of a child to express her comic criticism and in order to reveal the absurdities and incongruities of life. It is especially valid in the case of The House on Mango Street because her childhood memories are recounted but it is mostly true about the other two works likewise. Réka Cristian cites Cisneros' emphasizing that Esperanza's role is transgressive (2015), which, in my opinion, is mostly achieved by the humorous take on the accounts. Esperanza (and her sisters as well as friends) really hits holes on both her Latino/a-Chicano/a as well as American (meaning US) cultures/communities with her childish transgressions, questions and comments that have humorous effects, and it is so often the void, the black hole that pulls as into awareness and reality. With pointing out the incongruities and absurdities of life, Cisneros realizes what Nancy Walker states about humorists:

[b]ecause the humorist adopts at least the stance of superiority, claiming the freedom to point out incongruity or absurdity in a world that others are accustomed to accepting on its own terms, he or she works from a position of privileged insight. Mary Douglas suggests that the figure of the joker in many cultures occupies the position of a "minor mystic," having "apparent access to other reality than that mediated by the relevant structure [...]. His jokes expose the inadequacy of realist structurings of experience" (108) (1988: 25). 
This is exactly what Cisneros is doing in her stories in order to shed light on Latina existence often through the apparently naïve and ignorant questions and comments of a child - certainly all this serves an ironic project. Her works are exactly 'humor artistically enacted', in accordance with the definition of humor: they stand for "nonserious social incongruity" (Rod A. Martin, 2007: 6).

As Lora Romero and James Kyung-Jin Lee also state, her humor is that "fart in the bath" kind and "Cisneros's sense of outrageousness always made funnier, stronger, and deeper when shared with another as in her poem, 'Las Girlfriends': 'Been to hell and back again/Girl, me too"' (2006: 3032). But this Rabelaisian/Bakhtinian approach to life and storytelling makes her stories vivid, powerful and revelatory, while she never shies away from lifting the skirts and veils (and whatever necessary) in order to reveal the truth even if a stinky and melted Barbie foot is that sticking out; but "if you don't lift her dress, right? - who's to know.” (1999: 2699). The title of this story, Barbie- $Q$, is also a comic inversion of barbeque because a toy factory burns down, and the next day on the flea market, an enormous amount of damaged, smelly and half-melted toys are on sale for very low prices, and then, the girls can finally get all of the Barbie dolls, dresses and accessories etc. they want because otherwise their families would not have money for all that; so pain and disadvantage are converted into pirouettes even if the whole thing is a bit stinky and melted.

However, even more importantly, Sypher opines that the lower the comedy, the more authentic it is: "[...] the lower the range, the more authentic the comedy may be" (1956: 207). In order to reach a wider audience and make them understand and appreciate the message a "lowest common denominator" is needed that carries us to the depths of comedy as well as of truth and reality: "[a]t this depth comedy unerringly finds the lowest common denominator of human response, the reducing-agent that send us reeling back from our proprieties to the realm of old Pan" (Sypher, 1956: 207-208). According to his RabelaisianBakhtinian, carnivalesque comment: "[t] he unquenchable vitality of man gushes up from the lower strata of Rabelais' comedy [...]” (Sypher, 1956: 208). Sypher leaves the doors open for every person whether s/he chooses the comic or the tragic "road to wisdom," yet as he suggests, the comic way is always of better use because it is "more relevant to the human condition in all its normalcy and confusion, its many unreconciled directions," and "[c]omedy dares to seek truth" even "in the slums" and at the deepest recesses of human existence (1956: 254). This is why comedy always wins eventually and this is exactly what Cisneros is also doing.

Kay Young also sets out to compare the aesthetics of tragedy and comedy stating that while tragedy is a downward spiral with no return as a reaction to a sudden and unexpected occurrence comedy is an upward spiral as a response to the (same) unexpected and unprepared for occurrence that creates chaos as it is a "twist or turn that changes everything or reveals all at once what had been hidden or somehow unknown" (2013: 125). While tragedy is rigid and inflexible comedy is flexible, adaptable and variable. That is why the latter is for survival and advocates life as opposed to tragedy 
that is for death. Consequently, comedy is much more complex and intelligent concerning the matters of life as well as changes in (the conditions of) existence, thus it is able to find solutions to problems more effectively that assures survival and life, while tragedy is simplistic, (as a result) unintelligent, which is not able to adapt to changes and to find solutions to arising problems, hence it ends in death. Evidently, comedy "knows" much more about life than tragedy that is much more "familiar" with death. Stephen Hawking's now famous aphorism applies here: "Intelligence is the ability to adapt to change," so the comedic mode's adaptability and variability, which imply an intelligence that manages to define and understand a problem as well as to find a solution to it, make it an essential part of life, while tragedy's lack of all this excludes the possibility of survival. Hence, both tragedy and comedy are responses given to "the loss of control and mastery," yet, what makes comedy victorious is "inventiveness, quick-wittedness, playfulness, and the resilient rising" from the (same) fall that tragedy cannot return while it also regains control and mastery over life (Young, 2013: 125).

Young also cites Susanne Langer's philosophizing about this question involving evolutionary thinking. Langer concludes that a comic response is in accordance with "life's rhythm of adaptation," which means that any living thing strives to keep a balance to be able to persist; when this rhythm and living pattern is disturbed the organism gets out of balance and immediately tries "to retrieve its original dynamic form by overcoming and removing the obstacle" (Langer, 1953: 328 cited in Young, 2013: 125). When that organism does not manage to do that, then, it develops a variation and through the changes adapts to the new situation thus guaranteeing survival (Langer, 1953: 328 cited in Young, 2013: 125). As a consequence, the comic mode is a successful response to life while the tragic approach is a failed reaction to life. Eventually, it is our choice which way we choose to handle life in general or a given issue, the tragic or the comic approach, but Cisneros evidently opts for the comic survival and goes on telling and retelling her and others' stories of sadness as well as happiness to achieve redemption and secure life. She evidently shows the light at the end of the tunnel with her stories that are full of humor and humanity. As Simon Critchley also suggests based on various theoreticians: humor reveals something very essential about the human condition, about "the humanity" of human existence and human beings (2004: 25, 28, 35), while at the same time, it also "marks the limit of the human" (2004: 29). Cisneros connects all of us with her humor and suggests that eventually we are all just human and we all share something common since humor is also a "sensus communis" (Critchley, 2004: 18). 


\section{Works Cited}

Anzaldúa, Gloria (1987). Borderlands - La Frontera. The New Mestiza. San Francisco: Aunt Lute Books.

Barreca, Regina (ed.) (1996). The Penguin Book of Women's Humor. New York: Penguin Books.

Cisneros, Sandra (2004). Woman Hollering Creek. London: Bloomsbury.

Cisneros, Sandra (2002). Caramelo or Puro Cuento. New York: Vintage Books.

Cisneros, Sandra (1991). The House on Mango Street. New York: Vintage Books.

Cristian, Réka M. (2015). Home(s) on Borderlands and Inter-American Identity in Sandra Cisneros' Works. Americana, E-Journal of American Studies in Hungary, 11.1. Available at: http://americanaejournal.hu/vol11no1/cristian, access date: 10-11-2019.

Critchley, Simon (2004). On Humour. London and New York: Routledge.

Gilbert, Joanne R. (2004). Performing Marginality. Humor, Gender, and Cultural Critique. Detroit: Wayne State University Press.

Lauter, Paul (2006). The Heath anthology of American literature: Contemporary period: 1945 to the present. Boston: Houghton Mifflin.

Martin, Rod A. (2007). The Psychology of Humor: An Integrative Approach. Burlington: Elsevier Academic Press.

McQuade, Donald et al. (eds.) (1999). The Harper Single Volume American Literature. New York: Longman.

Sypher, Wylie (1956). The Meanings of Comedy. In: n.e. Comedy. Anchor Books edition. Garden City, New York: Doubleday Anchor Books, Doubleday \& Company, Inc. 193-255. Walker, Nancy A. (1988). A Very Serious Thing. Women's Humor and American Culture. Minneapolis: University of Minnesota Press.

Young, Kay (2013). "I'm Daphne," On the Comedy of Cross-Dressing and Metamorphosis in Wilder's Some Like It Hot, Lubitsch's I Don't Want to Be a Man, and Ovid's Metamorphoses. In: Peter Dickinson et al. (ed.) Women and Comedy. History, Theory, Practice. Madison: Fairleigh Dickinson University Press. 123-131. 